\title{
A COMPARISON OF NON-MANDATORY ONLINE DIALOGIC BEHAVIOR IN TWO HIGHER EDUCATION BLENDED ENVIRONMENTS
}

\author{
Paul Gorsky \\ Avner Caspi \\ Ina Blau \\ Open University of Israel
}

\begin{abstract}
This study compares dialogic behavior in asynchronous course forums from blended learning environments with non-mandatory student participation at a campus-based college and at a distance education, Open University. The goal is to document similarities and differences in students' and instructors' dialogic behavior that occur in two similar instructional resources used in two dissimilar learning environments. Quantitative content analysis, derived from the "Community of Inquiry" model, was performed on a year-long course forum from the college. These data were compared with composite data obtained previously from 50 Open University course forums. Findings showed that the dialogic behavior in the college forum differed greatly from the dialogic behavior exhibited in distance education forums. Specifically, the frequencies of "social presence", "teaching presence" and "cognitive presence" in the forums differed significantly. However, high frequencies of social presence coupled with low frequencies of cognitive presence at both institutions raise doubts regarding the popular assumption that deep and meaningful learning occurs in asynchronous course forums.
\end{abstract}

\section{KEYWORDS}

asynchronous forums, dialogic behavior, community of inquiry model, social presence, quantitative content analysis, distance education, higher education

\section{INTRODUCTION}

The "Community of Inquiry" framework [1,2] has become an accepted and widely used model that describes teaching and learning in fully online as well as in blended learning environments. The model assumes three dimensions or presences (social presence, teaching presence, and cognitive presence) through which dialogic behavior (verbal interactions) may be categorized. Considerable research has been conducted using the framework [3]. One particular line of inquiry, carried out by Gorsky and his colleagues, has been the search for recurrent patterns in the frequencies of social presence, cognitive presence, and teaching presence in higher education, asynchronous course forums with no demands for mandatory student participation. All the asynchronous course forums that Gorsky and his colleagues investigated were instructional resources which were part of blended learning environments. To date, a ratio for the frequencies of the three presences has been calculated $[4,5]$. This ratio $(\approx 60 \%: \approx 20 \%$ : $\approx 20 \%$, social presence, teaching presence and cognitive presence respectively) has been found stable across five variables: "academic discipline" (exact sciences vs. humanities), "academic level" (graduate vs. undergraduate), "course level" (introduction vs. regular vs. advanced), "group size" (small vs. medium vs. large) and "unit of analysis" (sentence vs. message). Given the recurrence of this ratio, we tentatively suggest that it may represent consistent behavior that holds for higher-education, asynchronous course forums with non-mandatory student participation. In other words, we speculate as to its generality beyond the particular samples from which it was derived. 
To date, the quantitative content analyses that established the frequency distribution have been carried out on graduate and undergraduate distance education, Open University course forums. The first objective of this investigation is to further corroborate the distribution's viability, that is, its "goodness-of-fit", across two different types of institutions for higher education, campus-based college versus distance education, Open University. The second objective of this investigation is to document similarities and differences that exist when forums are used as instructional resources at these institutions whose student populations and methods of teaching and learning are dissimilar.

In the following two sections, we discuss asynchronous course forums and content analysis, and the Community of Inquiry model that includes a summary of the research that led to hypothesizing the recurrent frequency distributions.

\section{A. Asynchronous Course Forums and Content Analysis}

Asynchronous course forums are used for teaching and learning in online and blended learning environments $[6,7,8]$. Educators have adopted online course forums widely and for diverse reasons. Nandi, Chang and Balbo [9] pointed out that the forum's asynchronous nature "enables learners and instructors to communicate with each other at anytime of the day, and without having to find the time for person-to-person interaction" (p. 666). Furthermore, whatever is posted on a forum may be accessible by all participants, anytime, anywhere. The transcript provides a means for researchers to analyze the kinds of dialogic behaviors that occurred in terms of critical thinking, e.g., [10, 2, 11], knowledge construction e.g., [12, 13] and/or metacognition e.g., [14]. In order to carry out such analyses, researchers often use "content analysis." Content analysis has been defined as "any technique for making inferences by objectively and systematically identifying specified characteristics of messages" [15].

Content analysis may be described in terms of two separate but complementary methodologies, quantitative and qualitative. Quantitative approaches to content analysis code communications and summarize them. Frequency distributions are calculated as a basis for comparison and statistical analysis. Qualitative approaches to content analysis are grounded in interpretive paradigms whose goals are to identify themes or categories within a transcript, and to provide a description of the social reality derived from those themes or categories in a particular setting. Both methodologies create categories to identify, classify, and measure dialogic behavior in social and cognitive processes.

Associated with the qualitative content analysis of higher education learning related groups, Henri [16] used a thematic unit. Murphy and Ciszewska-Carr [17] pointed out that Henri's thematic unit was later adopted in a number of other studies [18-24]. Associated with quantitative content analysis are structural units of analysis such as entire messages, sentences or even words. For example, Hara, Bonk and Angeli [25] used a paragraph; Aviv, Erlich, Ravid and Geva [26], Oriogun [27], Gorsky and Blau [28], and Gorsky et al. [4, 5] used the entire message; Fahy et al. [29] and Poscente and Fahy [30] chose the sentence. These researchers chose units of analysis in accord with their research objectives. For example, Poscente and Fahy [30] sought to identify strategic initial sentences (triggers) in computer conferencing transcripts. In line with this objective, the sentence is obviously the best unit of analysis. Aviv et el. [26] analyzed transcripts by message in an attempt to understand broad collaborative processes in asynchronous course forums. They innovatively assigned more than one code to a message if it included more than one type of behavior.

\section{B. The Community of Inquiry Model}

The Community of Inquiry (CoI) model was developed as an online learning research tool. The model provides a comprehensive theoretical framework for research into both online learning and the practice of online instruction as well as a methodology for carrying out quantitative content analysis [1, 31-34]. The model emerged in the specific context of computer conferencing in higher education, that is, asynchronous, text-based group discussions [33]. It remediated a lack of theoretical development in the field of online education and triggered a large amount of empirical studies [3, 34]. During the years 20002008, 48 studies that used the CoI model [35] were published and the body of research continues to grow 
rapidly, suggesting important implications for the design of successful e-learning [14, 33, 36]. The number of studies appears to be increasing exponentially given that a Google scholar search in February, 2012, seeking "Community of Inquiry" in article name, returned more than 1,000 items. The model will be described here briefly. Further details, if needed, may be found at the "Community of Inquiry" website (communitiesofinquiry.com).

The framework consists of three dimensions or presences. These incorporate categories, which, in turn, incorporate indicators that define each of the presences and guide the coding of transcripts. This structure is shown in table 1.

\begin{tabular}{|l|l|l|}
\hline Presences & Categories & Indicators (typical examples) \\
\hline \multirow{4}{*}{ Cognitive presence } & Triggering Event & Sense of puzzlement \\
\cline { 2 - 3 } & Exploration & Information exchange \\
\cline { 2 - 3 } & Integration & Connecting ideas \\
\cline { 2 - 3 } Social presence & Resolution & Apply new ideas \\
\cline { 2 - 3 } & Opfective & Expressing emotions \\
\cline { 2 - 3 } Teaching presence & Cohesion & Encouraging collaboration \\
\cline { 2 - 3 } & Design & Defining topics \\
\cline { 2 - 3 } & Direct instruction & Focusing discussion \\
\hline
\end{tabular}

Table 1. Community of Inquiry Coding Template (Garrison, Anderson and Archer, 2000)

The structure of the community of inquiry model has been confirmed through factor analysis [37-41]. All the same, modifications are still being made at the levels of category and indicator [34].

Cognitive presence is defined as the exploration, construction, resolution and confirmation of understanding through collaboration and reflection in a community of inquiry [11]. Cognitive presence is grounded in the work of Dewey [42]on reflective thinking, see further discussion[43]. Four categories (or phases) of cognitive presence are defined: triggering event, exploration, integration, and resolution. In essence, cognitive presence, especially the categories of integration and resolution which represent deep and meaningful learning, reflects the major goal of any learning process.

Social presence is described as the ability to project one's self and to establish personal and purposeful relationships [44]. The three main categories of social presence are affective communication, open communication, and group cohesion. The roles played by social presence include supporting discourse and setting a climate conducive to inquiry and learning [2]. Findings have shown the relation between social presence and perceived learning [45], between social presence and learning outcomes such as performance [46] and between social presence and learner satisfaction [47].

Teaching presence is defined as "the design, facilitation and direction of cognitive and social processes for the purpose of realizing [students'] personally meaningful and educationally worthwhile outcomes" [48, p.5]. Vygotsky's [49] scaffolding analogies illustrate an assistive role for teachers in providing instructional support to students from their position of greater content knowledge. The community of inquiry model defines three categories of teaching presence: design and organization, facilitating discourse, and direct instruction. The categories of teacher presence have been tested by Anderson et al. [48] in the analysis of the complete transcripts of two online courses and proved both reasonably reliable 
and useful in identifying differences in both the quantity and quality of the teaching presence projected by different online instructors.

The community of inquiry model has been illustrated schematically as shown in figure 1 [11].

\section{Community of Inquiry}

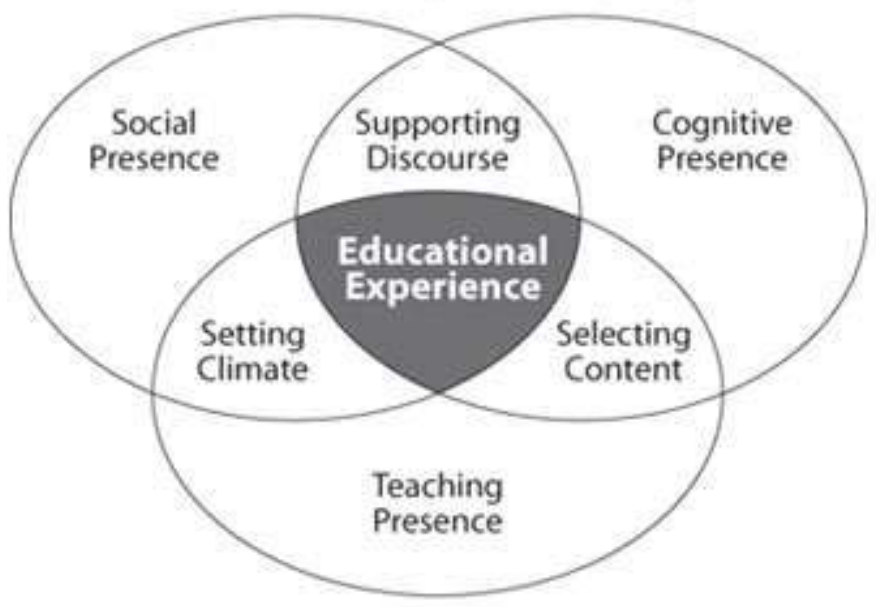

Figure 1. Community of inquiry model

In this schematic, the size assigned to each presence is equal. Gorsky and his colleagues [4] attempted to assign frequencies to the three presences and their associated categories in different kinds of forums. They used the quantitative content analysis technique derived from the "Community of Inquiry" model [2] to analyze three week segments from 50 undergraduate course forums, 25 from exact sciences and 25 from humanities, at the Open University of Israel. This goal of that study was to investigate the impact of academic discipline (exact sciences versus humanities) on dialogic behavior in course forums. Table 2 shows the frequency distributions of social presence, teaching presence and cognitive presence that were calculated.

\begin{tabular}{|l|l|l|l|l|}
\hline Distribution & $\begin{array}{l}\text { Social } \\
\text { Presence }\end{array}$ & $\begin{array}{l}\text { Teaching } \\
\text { presence }\end{array}$ & $\begin{array}{l}\text { Cognitive } \\
\text { presence }\end{array}$ & Totals \\
\hline Humanities & $65.87 \%$ & $18.98 \%$ & $15.15 \%$ & $100 \%$ \\
\hline Exact Sciences & $57.63 \%$ & $18.27 \%$ & $24.09 \%$ & $100 \%$ \\
\hline Science + Humanities & $61.75 \%$ & $18.63 \%$ & $19.62 \%$ & $100 \%$ \\
\hline
\end{tabular}

Table 2. Frequency distributions from Open Univ. course forums (Gorsky et al., 2010)

Two frequency distributions were noted, one for humanities forums and one for exact science forums. The mean distribution was also calculated. No statistically significant differences were found between the mean distribution and the humanities and sciences distributions.

Further analysis showed that the three frequencies were stable across academic level (undergraduate and graduate courses), course level (introductory, regular and advanced) and group size (small, medium and large), that is, the number of students enrolled in the course [4]. If these ratios are indeed stable across a wide range of settings (e.g., academic discipline, course level, etc.), then there may be a basic symmetry that exists within online, asynchronous instructional forums analyzed by a given tool (quantitative content analysis) grounded in a theoretical framework (community of inquiry). 


\section{The current study: Rationale and research questions}

This study compares dialogic behavior in asynchronous course forums from blended learning environments with non-mandatory student participation at a campus-based college and a distance education, Open University. The goal is to document similarities and differences in students' and instructors' dialogic behavior that occurs in two similar instructional resources with similar institutional goals (to enhance teaching and learning) used in two dissimilar learning environments. The research questions are:

Will the frequencies of social presence, teaching presence and cognitive presence calculated from Open University humanities forums hold for a humanities course forum in a campus based college?

What similarities and differences exist in the dialogic behavior exhibited by students and instructors in the Open University forums and a college forum? In other words, what inferences can be made from the rates of the three presences in the different forums?

\section{METHODOLOGY}

\section{A. Background}

The Open University of Israel is a distance education university that offers undergraduate and graduate studies to students throughout Israel. The learning environment is blended: The University offers a learning method based on printed textbooks, face-to-face tutorials, and an online learning content management system (LCMS) wherein each course has its own website. Course sites simplify organizational procedures and enrich students' learning opportunities and experiences. Website use is optional, non-mandatory so that equality among students is preserved. It does not replace textbooks or face-to-face tutorials, which are the pedagogical foundations of the Open University. The website provides forums for asynchronous instructor-student and student-student interactions. Each course has a coordinator, who is responsible for all administrative and academic activities, and instructors, who lead tutorials. Instructors and coordinators are available for telephone consultations at specified days and times. These forums are intended to be important resources for both teaching and learning.

The campus-based, academic college is in northern Israel; it offers undergraduate studies only. The learning environment for the particular humanities course being investigated is blended: based primarily upon lectures that generally included some question and answer discussion, it also included a course website and forum. The lecturer was available during office hours and, depending upon circumstances, could be approached prior to and after lectures. Course sites exist to simplify organizational procedures and to enrich students' learning opportunities and experiences. Website use is non-mandatory. It is managed by the lecturer and provides asynchronous instructor-student and student-student interactions. Like their Open University counterparts, these forums, by definition, are intended to be important resources for both teaching and learning.

\section{B. Sample}

The sample included two elements:

Frequency distributions shown in Table 1 that were derived from a previous study of 50 undergraduate course forums, 25 from exact sciences and 25 from humanities, at the Open University of Israel [4]. These distributions emerged from the analysis of 1,793 messages, 601 posted by instructors and 1,192 by students.

The transcript of an entire forum from a year long undergraduate course ("The History of War") at the campus-based college. It included 188 messages, 86 posted by instructors and 102 by students.

\section{Instrument}

The quantitative content analysis technique was used to code and analyze transcriptions from the forum. This technique has been widely used; it is reliable and valid [39]. Its implementation, however, requires 
that several methodological issues be resolved [33].

One issue is the level of coding (e.g., indicator vs. category). Content analysis, as described by Rourke and Anderson [50], is time-consuming, and coding at the indicator level is difficult, often yielding poor reliability [17]. In this study, as in previous studies [28, 4] we coded at the category level in order to obtain a reliable, high-level overview of dialogic behavior.

A second issue is the unit of analysis. Rourke et al. [51] identified five units of analysis used in computer conferencing research: proposition units, sentence units, paragraph units, thematic units, and message units. While there has been some discussion around this issue [40, 52, 53], it remains a challenging decision influenced by research question and context. In the present study, as in our previous studies, we used the message unit. This unit was chosen since it affords a bird's eye view appropriate when searching for an underlying structure of dialogic behavior.

A third issue is scoring. As in the previous studies cited above, we analyzed each message and scored each of the 10 categories as either present or not present ( 1 or 0$)$. In other words, if a category occurred more than once in a given message (say, two distinct occurrences of "open communication"), we recorded present only once. We did not count multiple recurrences of a category within the same message or sentence. Codes were recorded in a spreadsheet. Each row represents a message. Table 3 shows a typical layout.

\begin{tabular}{|c|c|c|c|c|c|c|c|c|c|}
\hline \multicolumn{3}{|c|}{ Social presence } & \multicolumn{3}{c|}{ Teaching presence } & \multicolumn{4}{c|}{ Cognitive presence } \\
\hline Affective & $\begin{array}{c}\text { Open } \\
\text { com. }\end{array}$ & Cohesion & Design & Discourse & Instruction & Trigger & Exploration & Integration & Resolution \\
\hline & & & & & & & & & \\
\hline
\end{tabular}

Table 3. A Typical Layout for Scoring Protocols

The rationale for this scoring method follows: When analyzing a message, it is taken in its entirety; for example, either the category "trigger" is present or not. If it is present more than once, then it is present in an additional sentence. In other words, such analysis would be taking place at the level of sentence, not message.

Other issues are objectivity, reliability, and replicability [52]. No established standards exist for inter-rater reliability [54]. There is no consensus for the percent agreement statistic. Often a cut-off figure of $75 \%$ $80 \%$ is used to determine reliability; others use $70 \%[55,52]$.

\section{Procedure and Data Analysis}

Two different raters took part in this study: Rater A (Author 3) is a senior faculty member at the Open University of Israel and an expert in the field of quantitative content analysis. She trained rater B, a graduate student working toward her degree in educational technology. Training included participation in a three-hour workshop that dealt with the theoretical basis of the CoI model and with the practical applications of quantitative content analysis. After the workshop, the trainee, Rater B, continued analyzing transcripts (excluded from the final inter-rater agreement test) until she reached high inter-rater agreement with the instructor, Rater A.

Rater B then analyzed the entire transcript of the forum from the campus-based college. Upon completion, Rater A randomly chose $25 \%$ of postings and re-analyzed them; $90 \%$ agreement was achieved (Cohen's $\kappa=0.88$ ).

\section{RESULTS}

Table 4 shows findings from this study (College) alongside the calculated frequency distributions from the Open University forums.

\begin{tabular}{|l|l|l|l|l|l|}
\hline Institution & Disciplines & $\begin{array}{l}\text { Social } \\
\text { presence }\end{array}$ & $\begin{array}{l}\text { Teaching } \\
\text { presence }\end{array}$ & $\begin{array}{l}\text { Cognitive } \\
\text { presence }\end{array}$ & Totals \\
\hline
\end{tabular}




\begin{tabular}{|l|l|l|l|l|l|}
\hline College & Humanities & $63.72 \%$ & $31.18 \%$ & $5.10 \%$ & $100 \%$ \\
\hline Open University & Humanities & $65.87 \%$ & $18.98 \%$ & $15.15 \%$ & $100 \%$ \\
\hline Open University & Science + Humanities & $61.75 \%$ & $18.63 \%$ & $19.62 \%$ & $100 \%$ \\
\hline & & & & & \\
\hline
\end{tabular}

Table 4. Frequency distributions from the Open University and College Forums

There is a statistically significant difference $\left\{\chi^{2}(2)=54.96, p<.001\right\}$ between the frequencies obtained for the three presences from the campus-based college forum (a humanities course) and the Open University forums in the humanities. Also, there is a statistically significant difference $\left\{\chi^{2}(2)=46.45, p<.001\right\}$ between the frequencies obtained from the college forum and the frequencies from the Open University science and humanities courses. In other words, it appears that, at best, the frequencies obtained from the Open University courses (the proposed stable frequencies) are appropriate only for forums at distance education institutions or, at worst, for the particular Open University being investigated.

There are, however, striking similarities in the proportions of social presence in the three distributions. When viewing the frequencies along two dimensions, social presence versus the sum of cognitive and teaching presence, there is no significant difference between the distributions from the college course forum and the distribution from the Open University humanities forums $\left\{\chi^{2}(1)=0.174, p=.68\right\}$ and the mean frequencies from the Open University science and humanities courses $\left\{\chi^{2}(1)=0.09, p=.76\right\}$. These similarities point toward revised frequencies (this time two-dimensional) that fit all previous and current data.

In order to gain a deeper understanding of the differences between forums at the two different kinds of institutions, we next investigated the dialogic behavior of instructors and students at levels of presence and category. The frequencies for instructors at the level of presence are shown in table 5.

\begin{tabular}{|l|l|l|l|}
\hline Institution & $\begin{array}{l}\text { Social } \\
\text { presence }\end{array}$ & $\begin{array}{l}\text { Teaching } \\
\text { presence }\end{array}$ & $\begin{array}{l}\text { Cognitive } \\
\text { presence }\end{array}$ \\
\hline College & $64.88 \%$ & $31.56 \%$ & $3.56 \%$ \\
\hline Open Univ. & $50.88 \%$ & $37.32 \%$ & $11.80 \%$ \\
\hline
\end{tabular}

Table 5. Frequency distributions for instructors at Open Univ. and College Forums

Significant differences were observed for instructors at the two different institutions. $\{\chi 2(2)=19.52$, $\mathrm{p}<.001\}$. In order to more fully understand the differences, frequencies at the level of category are shown in table 6.

\begin{tabular}{|l|l|c|c|c|c|}
\hline \multirow{3}{*}{ Presence } & \multirow{2}{*}{ Category } & \multicolumn{2}{|c|}{$\begin{array}{c}\text { Open } \\
\text { University }\end{array}$} & \multicolumn{2}{c|}{$\begin{array}{c}\text { Campus-based } \\
\text { College }\end{array}$} \\
\cline { 3 - 6 } & & $\#$ & $\%$ & $\#$ & $\%$ \\
\hline \multirow{3}{*}{ Teaching } & Design & 56 & $23.9 \%$ & 46 & $64.8 \%$ \\
\cline { 2 - 6 } & Discourse & 21 & $9.0 \%$ & 2 & $2.8 \%$ \\
\cline { 2 - 6 } & Direct instruction & 157 & $67.1 \%$ & 23 & $32.4 \%$ \\
\cline { 2 - 6 } & Totals & $\mathbf{2 3 4}$ & $\mathbf{1 0 0} \%$ & 71 & $\mathbf{1 0 0 \%}$ \\
\hline \multirow{2}{*}{} & Affective & 9 & $2.8 \%$ & 5 & $3.5 \%$ \\
\hline
\end{tabular}


A Comparison of Non-Mandatory Online Dialogic Behavior in Two Higher Education Blended Environments

\begin{tabular}{|l|l|c|c|c|c|}
\hline Social & Open com. & 173 & $54.2 \%$ & 77 & $52.7 \%$ \\
\cline { 2 - 6 } & Cohesion & 137 & $43.0 \%$ & 64 & $43.8 \%$ \\
\cline { 2 - 6 } & Totals & $\mathbf{3 1 9}$ & $\mathbf{1 0 0} \%$ & $\mathbf{1 4 6}$ & $\mathbf{1 0 0 \%}$ \\
\hline \multirow{4}{*}{ Cognitive } & Trigger & 10 & $11.9 \%$ & 1 & $12.5 \%$ \\
\cline { 2 - 6 } & Exploration & 68 & $81.0 \%$ & 5 & $62.5 \%$ \\
\cline { 2 - 6 } & Integration & 6 & $7.1 \%$ & 2 & $25.0 \%$ \\
\cline { 2 - 6 } & Resolution & 0 & $0 \%$ & 0 & $0 \%$ \\
\cline { 2 - 6 } & Totals & $\mathbf{8 4}$ & $\mathbf{1 0 0} \%$ & $\mathbf{8}$ & $\mathbf{1 0 0} \%$ \\
\hline
\end{tabular}

Table 6. Teaching, Social, and Cognitive Presence by Categories: Instructors only

Significant differences were noted for the three categories of teaching presence $\left\{\chi^{2}(2)=41.04, p<.001\right\}$. No significant differences were noted for the three categories of social presence $\left\{\chi^{2}(2)=0.18, p=.91\right\}$ and for cognitive presence by designated by two categories (trigger + a conglomerate of all three higher levels) $\left\{\chi^{2}(1)=0.27, p=.60\right\}$. For statistical analysis, given the sparse number of occurrences for the latter three categories of cognitive presence, they were united.

We next analyzed frequencies of teaching presence, cognitive presence and social presence for students only. Table 7 shows these data.

\begin{tabular}{|l|l|l|l|}
\hline & $\begin{array}{l}\text { Social } \\
\text { presence }\end{array}$ & $\begin{array}{l}\text { Teaching } \\
\text { presence }\end{array}$ & $\begin{array}{l}\text { Cognitive } \\
\text { presence }\end{array}$ \\
\hline College & $60.68 \%$ & $33.22 \%$ & $6.10 \%$ \\
\hline Open Univ. & $80.32 \%$ & $2.73 \%$ & $16.95 \%$ \\
\hline
\end{tabular}

Table 7. Frequency distributions for students at Open Univ. and College Forums

Statistically significant differences were found for the distributions of the 3 presences $\left\{\chi^{2}(2)=191.65, p<.001\right\}$. Frequencies at the level of category are shown in table 8.

\begin{tabular}{|l|l|c|c|c|c|}
\hline \multirow{3}{*}{ Presence } & \multirow{2}{*}{ Category } & \multicolumn{2}{|c|}{$\begin{array}{c}\text { Open } \\
\text { University }\end{array}$} & \multicolumn{2}{c|}{$\begin{array}{c}\text { Campus-based } \\
\text { College }\end{array}$} \\
\cline { 3 - 6 } & & $\#$ & $\%$ & $\#$ & $\%$ \\
\hline \multirow{4}{*}{ Teaching } & Design & 15 & $79 \%$ & 81 & $92 \%$ \\
\cline { 2 - 6 } & Discourse & 1 & $5.2 \%$ & 11 & $1.2 \%$ \\
\cline { 2 - 6 } & Direct instruction & 3 & $15.8 \%$ & 6 & $6.8 \%$ \\
\cline { 2 - 6 } & Totals & $\mathbf{1 9}$ & $\mathbf{1 0 0} \%$ & $\mathbf{9 8}$ & $\mathbf{1 0 0} \%$ \\
\hline \multirow{4}{*}{ Social } & Affective & 69 & $12.3 \%$ & 21 & $11.7 \%$ \\
\cline { 2 - 6 } & Open com. & 292 & $52.3 \%$ & 73 & $40.8 \%$ \\
\cline { 2 - 6 } & Cohesion & 198 & $35.4 \%$ & 85 & $47.5 \%$ \\
\cline { 2 - 6 } & Totals & 559 & $\mathbf{1 0 0} \%$ & $\mathbf{1 7 9}$ & $\mathbf{1 0 0 \%}$ \\
\hline
\end{tabular}




\begin{tabular}{|c|l|c|c|c|c|}
\hline & Trigger & 75 & $63.5 \%$ & 14 & $77.8 \%$ \\
\cline { 2 - 6 } Cognitive & Exploration & 42 & $35.6 \%$ & 4 & $22.2 \%$ \\
\cline { 2 - 6 } & Integration & 1 & $0.9 \%$ & 0 & 0 \\
\cline { 2 - 6 } & Resolution & 0 & 0 & 0 & 0 \\
\cline { 2 - 6 } & Totals & $\mathbf{1 1 8}$ & $\mathbf{1 0 0} \%$ & $\mathbf{1 8}$ & $\mathbf{1 0 0 \%}$ \\
\hline
\end{tabular}

Table 8 Teaching, Social, and Cognitive Presence by Categories: Students only

A significant difference was noted for the three categories of social presence $\left\{\chi^{2}(2)=140.59, \mathrm{p}<.0001\right\}$. No significant differences were noted for the three categories of teaching presence $\left\{\chi^{2}(2)=2.51, \mathrm{p}<.29\right\}$ and for the two categories of cognitive presence (trigger + a conglomerate of all three higher levels) $\left\{\chi^{2}(1)=0.84, p=.36\right\}$.

\section{DISCUSSION AND CONCLUSIONS}

We address the following issues: (1) Differences between distance education Open University and campus-based college course forums that can be inferred from the quantitative content analyses carried out, (2) The relationship between the frequency distributions derived from distance education, Open University asynchronous course forums and those from the campus-based college forum and (3) The role of social presence in online learning mediated by asynchronous course forums.

\section{A. Differences between distance education, Open University and campus- based college course forums}

Findings presented in Table 4 showed significant differences between the distributions of teaching presence and cognitive presence in course forums at the two institutions. At the campus-based college, teaching presence was more than 50\% higher than at the Open University, while cognitive presence in the Open University courses was 3-4 times greater.

Further analysis (Table 6) showed that instructors' teaching presence at the college was expressed primarily through the category "design and organization" (\%79.9). According to Anderson et al. (2001), "design and organization" is manifested by setting curriculum, designing methods, establishing time frames, etc. Teaching presence at the Open University was expressed primarily through the category "direct instruction" (63.2\%). This category is manifested by presenting content and related questions, focusing the discussion on specific issues, summarizing the discussion, confirming understanding through assessment and explanatory feedback, etc. [48].

These differences in how teaching presence is manifested in the forums may possibly reflect institutional differences vis-a-vis teaching; that is, college students were exposed to "direct instruction" in their classroom lectures and had little or no need for such dialogic behavior in the forum. The college lecturer utilized the forum for the "design and organization" of the subject matter already presented in the lectures. As opposed to this format, Open University instructors used the forum primarily for "direct instruction", that is, to teach material presented to the distance education students in their texts.

Furthermore, vis-à-vis learning, the near absence of "cognitive presence" (5.1\%) in the undergraduate college forum indicates that the forum was not utilized primarily for learning subject matter. This is reasonable since college students attended weekly lectures, had ample opportunity to talk with instructors and to establish friendships with classmates. Rates of cognitive presence were about three times higher in the undergraduate course forums at the Open University where students met less frequently with instructors and peers.

Despite significant differences in the amounts and kinds of teaching and cognitive presence exhibited, findings from both institutions show clearly the similar high rates of social presence in asynchronous course forums $[45,28,56]$. 


\section{B. Revised frequencies for higher education asynchronous course forums}

No significant difference was found in the proportion of social presence between the forum analyzed at the campus-based college and the humanities forums at the Open University. In addition, no significant difference was found in the proportion of social presence between the forum analyzed at the campusbased college and the science + humanities forums at the Open University.

In light of these findings, we propose a two-dimensional ratio for higher education, asynchronous course forums from blended learning environments without mandatory participation whose goodness-of-fit is stable across six variables: academic discipline, academic level, course level, group size, unit of analysis and institutional difference. The proposed ratio for social presence versus the sum of teaching presence and cognitive presence is $61.75: 38.25$.

At this point, we clearly emphasize the obvious - namely, the analysis of one forum, albeit an entire forum for an entire year, is not representative of all "college-based humanities forums"; additional research is needed to corroborate such a claim. However, for research purposes, this study it is a useful starting point. Going further, we reiterate that these and previous findings cited above are relevant only for dialogic behavior in asynchronous course forums from blended learning environments without mandatory participation. Several interesting research questions are derived from these limitations:

- Would results be different if participation were mandatory?

- Would results be different if the forums studied were from a purely online course?

We have no theoretical base or previous empirical findings for hypothesizing. However, it seems reasonable to assume that dialogic behavior, when analyzed at the level of category, would differ in each of the two above cases (parallel to findings in this study). In our view, however, the most intriguing question is whether the ratio for social presence versus the sum of teaching presence and cognitive presence is (61.75 : 38.25) would hold in such very different environments. If so, this might point to a deep finding that shows the importance of social presence in higher education forums devoted to teaching and learning.

\section{The roles of social presence in online learning}

In this and in our previous studies cited above, we found that the total amount of social presence (instructors and students) in a typical higher education course discussion forum (in a blended learning environment with non-mandatory participation) accounts for about $60 \%$ of the content in the transcripts analyzed. In this section, we review briefly the roles assigned to social presence in such asynchronous discussion groups; we will show that the relationship between actual and perceived learning and the dynamics of social presence (as well as all three presences) remains unclear. Furthermore, in light of findings and conclusions reported by Rourke and Kanuka [35], we, as they do, call into question the basic premise that underlies the Community of Inquiry model, namely that deep and meaningful learning arises in CoI.

Theoretically, the relationship between the three presences and learning outcomes is grounded in "social constructivism" [49] which contends that learning is shaped by "social context." Swan [57] pointed out the importance of social constructivism to online learning:

Social constructivism reminds us that learning is essentially a social activity, that meaning is constructed through communication, collaborative activity, and interactions with others. It highlights the role of social interactions in meaning making ... (and) knowledge construction (p. 5).

Given this theoretical base, we assumed that a relatively large body of research would link social presence (as well as all three presences) to learning outcomes. However, this was not the case. Rourke and Kanuka [35], after reviewing 252 publications and reports from 2000--2008 that referenced the CoI framework, found that of the 48 studies that "collected and analyzed data on one or more aspects of the CoI 
framework, only five included a measure of student learning" (p.19). They also noted that, for the most part, learning was defined as perceived learning and assessed with a single item on a closed-form survey. They expressed concerns regarding the "soundness of such measures;" in other words, the very validity of these findings. Some examples follow.

Regarding the relationship between social presence and actual learning outcomes, Akyol, Garrison, and Ozden [3] found social presence "an important antecedent to collaboration and critical discourse because it facilitates achieving cognitive objectives by instigating, sustaining, and supporting critical thinking in a community of learners" (p. 67). They noted that students value social presence as a way to "share ideas, to express views, and to collaborate" (p. 76). Jung et al. [46] assessed the relationship between social interactivity and learning outcomes; they concluded that students' social interaction with instructors and collaborative interaction with peers are important in enhancing their learning and active participation in online discussion.

Regarding perceived learning, Shea, Li, and Pickett [58] and Akyol and Garrison [59] surveyed students' perceived learning by asking them to what extent they learned in online courses. Both studies report a significant positive correlation between increased social presence and perceived learning. Picciano [60] found a high, positive correlation (.67) between perceived social presence and perceived learning, but no statistically significant correlation between perceived social presence and grades in the final exam. Richardson and Swan [61] found that $42 \%$ of the variability in perceived learning was predicted by perceived social presence. Swan and Shea [62] found a high correlation (.70) between perceived social presence and perceived learning. Hornik and Tupchiy [63] found a positive correlation (.38) between social presence and perceived learning but only a weak correlation (.12) between social presence and actual performance. Arnold and Ducate [64] found that social activity outweighed cognitive events and accounted for $58-67 \%$ of the total events; nevertheless most students perceived a high level of learning. Caspi and Blau [45] found relationships between students' perceptions of social presence and their perceived learning. The positive correlation between perceived social presence and most aspects of perceived learning led them to the tentative conclusion that social presence affords learning by setting a convenient climate.

In contrast to these findings, Shea and Bidjerano [41] noted that asynchronous group-based communications per se are insufficient to develop an effective community of inquiry, and this was also the main point made by Garrison and Cleveland-Innes [65]. However, the important unexamined question is whether social presence is indeed necessary at all to facilitate the development of higher-order cognitive presences and subsequent deep and meaningful learning.

Rourke and Kanuka [35] went so far as to conclude that "it is unlikely that deep and meaningful learning arises in CoI" (p.19). This conclusion is supported by findings from this study. Table 9 shows the distributions of the categories of cognitive presence. The categories "trigger" and "exploratory" represent initial phases of cognitive presence while the categories "integration" and "resolution" represent "deep and meaningful learning". Only a negligible amount of dialogic behavior representing "deep and meaningful learning" was recorded.

\begin{tabular}{|l|c|c|c|c|}
\hline & \multicolumn{2}{|c|}{ Trigger + } & \multicolumn{2}{c|}{ Integration + } \\
& Exploratory & \multicolumn{2}{c|}{ Resolution } \\
\cline { 2 - 5 } & $\mathrm{n}$ & $\%$ & $\mathrm{n}$ & $\%$ \\
\hline Open Univ. & 195 & $96.5 \%$ & 7 & $3.5 \%$ \\
\hline College & 24 & $92.3 \%$ & 2 & $7.7 \%$ \\
\hline
\end{tabular}

Table 9. Distributions of the categories of cognitive presence

To conclude, whether and how social interaction affects actual learning in asynchronous discussion groups remains unclear and constitutes an important area for future research. Even more, further research 
is required to determine if deep and meaningful learning can actually be obtained via the use of such resources.

\section{ABOUT THE AUTHORS}

Dr. Paul Gorsky is a faculty member in the Department of Education and Psychology at the Open University of Israel where his research is directed toward theories of instruction, instructional technology and the development of personal, intelligent and adaptive instructional systems. He is also Chairman of the Board of Directors of a not-for-profit organization that offers extra-curricular, hands-on, inquiry based science enrichment programs for more than a thousand gifted and "science oriented" youth throughout Israel. CV: http://www.openu.ac.il/Personal sites/paul-gorsky/.

Dr. Avner Caspi received his Ph.D. in Cognitive Psychology at Tel Aviv University. He is a senior faculty member in the Department of Education and Psychology at the Open University of Israel. His research interests include instructional theory, the role of dialogue in instructional systems, sociopsychological aspects of Internet use, and individual differences. His publications are on his personal website: http://www.openu.ac.il/Personal_sites/avner-caspi.html.

Dr. Ina Blau holds a Ph.D. in E-Learning and Cyber-Psychology from the University of Haifa, Israel. She is a senior faculty member in the Department of Education and Psychology at the Open University of Israel. In addition, she teaches in the Department of Information and Knowledge Management, Graduate School of Management, University of Haifa. Her research interests include social aspects of Internet use and e-communication, online risks and safety, participation patterns, e-collaboration, as well as the integration of innovative technologies in education systems and organizations. Her CV is at: http://www.openu.ac.il/Personal sites/ina-blau/.

\section{REFERENCES}

1. Garrison, D.R., and Anderson, T., E-learning in the $21^{\text {st }}$ Century, London: Rutledge Falmer, 2003.

2. Garrison, D.R., Anderson, T., and Archer, W. Critical inquiry in a text-based environment: Computer conferencing in higher education. The Internet and Higher Education 2: 87-105 (2000).

3. Akyol, Z., Garrison, D.R., and Ozden, M.Y. Online and blended communities of inquiry: Exploring the developmental and perceptional differences. The International Review of Research in Open and Distance Learning 10: 65-83 (2009).

4. Gorsky, P., Caspi, Antonovsky, A., Blau, I. and Mansur, A. The relationship between academic discipline and dialogic behavior in Open University course forums. International Review of Research on Distance Learning 11 (2010).

5. Gorsky, P., Caspi, A., Blau, I., Vine, Y. and Billet, A. Toward a Community of Inquiry population parameter: The impact of unit (sentence vs. message) on the results of quantitative content analysis. International Review of Research on Distance Learning 12 (2012).

6. Guzdial, M., and Turns, J. Effective discussion through a computer-mediated anchored forum. The Journal of the Learning Sciences 9: 437-469 (2000).

7. Sharples, M. The design of personal mobile technologies for lifelong learning. Computers and Education 34: 177-193 (2000).

8. Tallent-Runnels, M., Thomas, J., Lan, W., Cooper, S., Ahern, T., Shaw, S., and Liu, X. Teaching Courses Online: A Review of the Research. Review of Educational Research 76: 93-135 (2006).

9. Nandi, D., Chang, S., and Balbo, S., A conceptual framework for assessing interaction quality in online discussion forums. In: Same places, different spaces. Proceedings ascilite Auckland. 2009. http://www.ascilite.org.au/conferences/auckland09/procs/nandi.pdf. 
10. Fahy, P.J. Two methods for assessing critical thinking in computer-mediated communications (CMC) transcripts. International Journal of Instructional Technology and Distance Learning (2005). http://www.itdl.org/Journal/Mar_05/article02.htm.

11. Garrison, D.R., Anderson, T., and Archer, W. Critical thinking and computer conferencing: A model and tool to assess cognitive presence. American Journal of Distance Education 15: 7-23 (2001).

12. De Wever, B., Van Keer, H., Schellens, T., and Valcke, M. Roles as a structuring tool in online discussion groups: The differential impact of different roles on social knowledge construction. Computers in Human Behavior 26: 516-523 (2010).

13. Hwee Ling Koh, J., Herring, S., and Foon Hew, K. Project-based learning and student knowledge construction during asynchronous online discussion, The Internet and Higher Education 14: 284291 (2010).

14. Akyol, Z., and Garrison, D.R. Assessing metacognition in an online community of inquiry, The Internet and Higher Education 14(3): 183-190 (2011).

15. Holsti, O.R., Content analysis for the social sciences and humanities, Reading, MA: AddisonWesley, 1969.

16. Henri, F., Computer conferencing and content analysis. In: Kaye, A.R. (Ed), Collaborative learning through computer conferencing, Berlin: Springer Verlag, 117-136, 1992.

17. Murphy, E., and Ciszewska-Carr, J. Sources of difference in reliability: Identifying sources of difference in reliability in content analysis of online asynchronous discussions. International Review of Research in Open and Distance Learning 6 (2005). http://www.irrodl.org/index.php/irrodl/article/view/233/855.

18. Aviv, R. Educational performance of ALN via content analysis. Journal of Asynchronous Learning Networks 4: 53-72 (2001).

19. Gunawardena, C., Lowe, C. A., and Anderson, T. Analysis of a global online debate and the development of an interaction analysis model for examining social construction of knowledge in computer conferencing. Journal of Educational Computing Research 17: 397-431 (1997).

20. Howell-Richardson, C., and Mellar, H. A methodology for the analysis of patterns of interactions of participation within computer mediated communication courses. Instructional Science 24: 47-69 (1996).

21. Jeong, A.C. The sequential analysis of group interaction and critical thinking in online threaded discussions. The American Journal of Distance Education 17: 25-43 (2003).

22. McDonald, J., Interpersonal group dynamics and development in computer conferencing: The rest of the story. In: Proceedings of the 14th conference on distance teaching and learning, Madison, WI: Continuing and Vocational Education, University of Wisconsin-Madison, 1998.

23. Newman, D.R., Webb, B., and Cochrane, C. A content analysis method to measure critical thinking in face-to-face and computer supported group learning. Interpersonal Computing and Technology Journal 3: 56-77 (1995).

24. Turcotte, S., and Laferrière, T. Integration of an online discussion forum in a campus-based undergraduate biology class. Canadian Journal of Learning and Technology 30: 73-92 (2004).

25. Hara, N., Bonk, C.J., and Angeli, C. Content analyses of on-line discussion in an applied educational psychology course. Instructional Science 28: 115-152 (2000).

26. Aviv, R., Erlich, Z., Ravid, G., and Geva, A. Network analysis of knowledge construction in asynchronous learning networks. Journal of Asynchronous Learning Networks 7: 1-23 (2003).

27. Oriogun, P.K. Towards understanding online learning levels of engagement using the SQUAD approach to CMC discourse. Australian Journal of Educational Technology 19: 371-387 (2003).

28. Gorsky, P., and Blau, I. Effective online teaching: A tale of two instructors. International Review of Research on Distance Learning 10(3): 1-27 (2009).

29. Fahy, P.J., Crawford, G., Ally, M., Cookson, P., Keller, V., and Prosser, F. The development and testing of a tool for analysis of computer mediated conferencing transcripts. Alberta Journal of Education Research 46: 85-88 (2000). 
30. Poscente, K.R., and Fahy, P.J. Investigating triggers in CMC text transcripts. International Review of Research in Open and Distance Learning 4 (2003). http://www.irrodl.org/content/v4.2/poscente_fahy.html.

31. Akyol, Z. Arbaugh, J.B., Cleveland-Innes, M., Garrison, D.R., Ice, P., Richardson, J.C., and Swan, K. A response to the review of the Community of Inquiry framework. Journal of Distance Education 23: 123-136 (2009).

32. Arbaugh, J.B., Bangert, A., and Cleveland-Innes, M. Subject matter effects and the community of inquiry (CoI) framework: An exploratory study. The Internet and Higher Education 13: 37-44 (2010).

33. Garrison, D.R., Anderson, T., and Archer, W. The first decade of the community of inquiry framework: A retrospective. The Internet and Higher Education 13: 5-9 (2010).

34. Shea, P., Hayes, S., Vickers, J., Gozza-Cohen, M., Uzuner, S., Mehta, R., Valchova, A., and Rangan, P. A re-examination of the community of inquiry framework: Social network and content analysis. The Internet and Higher Education 13: 10-21 (2010).

35. Rourke, L., and Kanuka, H. Learning in communities of inquiry: A review of the literature. Journal of Distance Education 23: 19-48 (2009).

36. Shea, $\mathbf{P}$., and Bidjerano, T. Cognitive presence and online learner engagement: A cluster analysis of the community of inquiry framework. Journal of Computing in Higher Education 21: 199-217 (2009).

37. Arbaugh, J.B. Does the community of inquiry framework predict outcomes in online MBA courses? The International Review of Research in Open and Distance Learning 9: 1-12 (2008). http://www.irrodl.org/index.php/irrodl/article/view/490/1048.

38. Arbaugh, J. B., and Hwang, A. Does "teaching presence" exist in online MBA courses? The Internet and Higher Education 9: 9-21 (2006).

39. Garrison, D.R., and Arbaugh, J.B. Researching the community of inquiry framework: Review, issues, and future directions. Internet and Higher Education 10: 157-172 (2007).

40. Garrison, D. R., Cleveland-Innes, M., and Fung, T.S. Exploring causal relationships among teaching, cognitive and social presence: Student perceptions of the community of inquiry framework. The Internet and Higher Education 13: 31-36 (2010).

41. Shea, P., and Bidjerano, T. Community of inquiry as a theoretical framework to foster "epistemic engagement" and "cognitive presence" in online education. Computers and Education 52: 543-553 (2009).

42. Dewey, J., How we think (Revised edition), Boston: D.C. Heath, 1933.

43. Swan, K., Garrison, D.R., and Richardson, J., A constructivist approach to online learning: The community of inquiry framework. In: Payne, C.R. (Ed.), Information technology and constructivism in higher education: Progressive learning frameworks, Hershey, PA: IGI Global, 2009.

44. Caspi, A., and Blau, I. Online discussion groups: The relationship between social presence and perceived learning. Social Psychology of Education 11: 323-346 (2008).

45. Jung, I., Choi, S., Lim, C., and Leem, J. Effects of different types of interaction on learning achievement, satisfaction, and participation in web-based instruction. Innovations in Education and Teaching International 39(2): 153-162 (2002).

46. Gunawardena, C.N., and Zittle, F.J. Social presence as a predictor of satisfaction within a computer mediated conferencing environment. American Journal of Distance Education 11(3): 826 (1997).

47. Anderson, T., Rourke, L., Garrison, D.R., and Archer, W. Assessing teaching presence in a computer conferencing context. Journal of Asynchronous Learning Networks 5 (2001). http://sloanc.org/publications/jaln/v5n2/pdf/v5n2_anderson.pdf.

48. Vygotsky, L., Mind in society: The development of higher psychological processes, Cambridge MA: Harvard University Press, 1978.

49. Rourke, L., and Anderson, T. Validity issues in quantitative computer conference transcript analysis. Educational Technology Research and Development 52: 5-18 (2004). 
50. Rourke, L., Anderson, T., Garrison, D.R., and Archer, W. Assessing social presence in asynchronous test-based computer conferencing. Journal of Distance Education 14: 50-71 (1999). http://www.jofde.ca/index.php/jde/article/viewArticle/153/341.

51. Fahy, P.J. Addressing some common problems in transcript analysis. International Review of Research in Open and Distance Learning 1 (2001). http://www.irrodl.org/index.php/irrodl/article/view/321/530.

52. Rourke, L., Anderson, T., Garrison, D.R., and Archer, W. Methodological issues in the content analysis of computer conference transcripts. International Journal of Artificial Intelligence in Education 12: 8-22 (2001).

53. De Wever, B., Schellens, T., Valcke, M., and Van Keer, H. Content analysis schemes to analyze transcripts of online asynchronous discussion groups: A review. Computers and Education 46: 6-28 (2006).

54. Neuendorf, K.A., The content analysis guidebook, Thousand Oaks, CA: Sage Publications, 2002.

55. Vaughan, N., and Garrison, D.R. How blended learning can support a faculty development community of inquiry. Journal of Asynchronous Learning Networks 10 (2006). http://www.sloanc.org/publications/JALN/v10n4/v10n4_vaughan.asp.

56. Swan, K. A constructivist model for thinking about learning online. In: Bourne. J., and Moore, J.C. (Eds.), Elements of quality online education: Engaging communities, Needham, MA: Sloan-C., 1330, 2005.

57. Shea, P.J., Li, C.S., and Pickett, A. A study of teaching presence and student sense of learning community in fully online and web-enhanced college courses. Internet and Higher Education 9(3): 175-190 (2006).

58. Akyol, Z., and Garrison, D. R. The development of a community of inquiry over time in an online course: Understanding the progression and integration of social, cognitive and teaching presence. Journal of Asynchronous Learning Networks 12 (2-3): 3-23 (2008).

59. Picciano, A. Beyond student perceptions: Issues of interaction, presence, and performance in an online course. Journal of Asynchronous Learning Networks 6(1): 21- 40 (2002).

60. Richardson, J.C., and Swan, K. Examining social presence in online courses in relation to students' perceived learning and satisfaction. Journal of Asynchronous Learning Networks 7(1) (2003). http://www.aln.org/publications/jaln/v7n1/pdf/v7n1_richardson.pdf.

61. Swan, K., and Shea, P., The development of virtual learning communities. In: Hiltz, S.R., and Goldman, R. (Eds.), Asynchronous learning networks: The research frontier, New York: Hampton Press, 239-260, 2005.

62. Hornik, S., and Tupchiy, A. Culture's impact on technology mediated learning: The role of horizontal and vertical individualism and collectivism. Journal of Global Information Management 14(4): 31-56 (2006).

63. Arnold, N., and Ducate, L. Future foreign language teachers' social and cognitive collaboration in an online environment. Language Learning and Technology 10(1): 42-66 (2006).

64. Garrison, D.R., and Cleveland-Innes, M. Facilitating cognitive presence in online learning: Interaction is not enough. American Journal of Distance Education 19(3): 133-148 (2005). 